\title{
DETERMINANTS OF CUSTOMER'S CHOICE OF RETAIL OUTLET FOR THE PURCHASE OF FRUITS AND VEGETABLES
}

\author{
Oriyomi OSITADE ${ }^{1}$, Kehinde Paul ADEOSUN ${ }^{12 *}$ (iD), Bolarin Titus OMONONA ${ }^{1}$
}

\begin{abstract}
Address:
${ }^{1}$ Department of Agricultural Economics, Faculty of Agriculture, University of Ibadan, Oyo State, Nigeria.

${ }^{2}$ University of Nigeria Nsukka, Faculty of Agriculture, Department of Agricultural Economics, Main Campus Nsukka, 410001 Nsukka, Enugu State

* Corresponding author: paul.adeosun@unn.edu.ng
\end{abstract}

\begin{abstract}
Research background: Adequate and sufficient intake of fruits and vegetables has been listed as one of the important avenues for actualizing a healthy living. More so, access to fruits and vegetables through a preference for retail outlets is indispensable to the debate on fruits and vegetable consumption among households.

Purpose of the article: The study examines factors influencing the choice of retail outlets and frequency of visits to retail outlets for the purchase of fruits and vegetables.

Methods: The study employed multistage sampling to select the respondent for the study. Primary data were collected from 290 respondents through semi-structured questionnaires and were analysed using Descriptive statistics and Multinomial Logistic Regression.

Findings \& Value added: The results indicate that majority $(52.76 \%)$ of consumers preferred to purchase fruits and vegetables daily, weekly, and monthly, while $27.59 \%$ preferred to purchase fruits and vegetables weekly only. Regarding the choice of retail outlet, most $(46.21 \%)$ preferred both open market, neighbourhood stores, and supermarkets, while $33.10 \%$ preferred open market only for the choice of fruits and vegetables. The results also indicate important and significant factors like household size $(\mathrm{p}<0.1)$, number of people working within the household $(\mathrm{p}<0.05)$, total household income $(\mathrm{p}<0.05)$ that influenced the consumer's choice of retail outlet for fruits and vegetable. Likewise, important and significant factors such as customer service $(\mathrm{p}<0.05)$, sex of consumer $(\mathrm{p}<0.05)$, shopping habit $(\mathrm{p}<0.01)$ influenced the frequency of visits to fruit and vegetable retail outlets by consumers. The study recommended that retail outlet owners should strive to create a conducive and friendly atmosphere with their customers to engender an enduring customer service experience to encourage customers' repeat purchases.
\end{abstract}

Key words: retail outlets; fruits and vegetable; consumer's choice; socioeconomics; urban JEL Codes: D1; D5; C8; D12; Q11; Q12

\section{INTRODUCTION}

Adequate and sufficient intake of fruits and vegetables has been listed as one of the important avenues for actualizing a wish for healthy living. WHO (2003) reported that fruits and vegetables are indispensable food groups for human development and growth. In Nigeria, the consumption of fruits such as banana, apple, orange, grape, pear, and lemon and vegetables such as tomato, pepper, eggplant, lettuce, cucumber, garlic, carrot, and cabbage are undoubtedly common in the household food basket (Ogundari and Arifalo, 2013). Therefore, the importance of fruits and vegetable consumption among household members in Nigeria cannot be overemphasized. Additionally, WHO (2003) report revealed that low consumption of fruits and vegetables make people to be vulnerable to gastrointestinal cancer, ischemic heart disease, and stroke globally. Fruits and vegetables as part of the daily diet that could help prevent major non- communicable diseases (NCD). Moreover, eating a variety of vegetables and fruits ensures an adequate intake of most micronutrients, dietary fibres, and a host of essential non-nutrient substances.

Nigeria provides a large and attractive retail food industry including fruits and vegetable because of the major traditional foodstuffs consumed by the majority of the population. The examples of such food stuff include fruits, vegetables, corn, sorghum, tubers, and seafood (fish) which are predominantly unprocessed and/or semiprocessed. There has also been an increase in the establishment of large international and local supermarkets with several conveniences or neighbourhood retail stores springing up daily in all nooks and crannies within the cities. Government urban renewal activities have favoured and encouraged the establishment of these supermarkets and convenience stores because of the government's city development and investment objectives to the detriment of the development of 
traditional open-air markets. As a matter of fact, in some instances, government agencies purposely or clandestinely demolish the existing traditional open-air markets in urban centers and convert them into semimodern retail outlets to give the city a "befitting" appearance deserving of a developed metropolis. Some of these open-air markets display several raw food products ranging from cereals, roots, and tubers to fresh fruits and vegetables

Despite the urban renewal project of governments and their bias for the promotion of modern retail outlets, traditional open-air retail outlets are still the most frequented outlets in Nigeria. The evidence is based on the transactions percentage distribution among the 3 established trading platforms in Nigeria as outlined by a United States Department of Agriculture (Nzeka, 2011) report. This assertion is corroborated by Meng $\boldsymbol{e t}$ al., (2014) in their study in Ghana where open-air markets were found to continue to dominate the food retail system, with $70 \%$ of households reporting to patronize them at least once a week. Open-air markets are traditional food outlets particularly attractive to large households. More so, most households who are low-income earners prefer to engage open markets for their raw foods, particularly fruits and vegetables.

It is important to note that available literature by Ohen et al (2014), Layade and Adeoye (2014), and Ogundari and Arifalo (2013) on fruits and vegetables in Nigeria are focused primarily on the consumption, nutritional, health, and disease prevention. However, the previous studies did not expressly examine the factors influencing the choice of retail outlets where fruits and vegetables are purchased by consumers. Thus, it neglects or underestimates the important factors that may be responsible for the choice of retail outlets for fruits and vegetables. More so, we lack the understand of important factor and how they influence the choice of retail outlets for fruits and vegetable. Moreover, other studies that touched on consumer preferences for location of purchase either dwelt on the blanket grocery transactions (Nzeka, 2011) or under the general foodstuffs category with fruits and vegetables being just an item in the study as it relates to consumer's diet and nutrition (Meng et al 2014; Kapoor \& Kumar, 2015). This study, therefore, develops a better understanding of factors that influence customers' preference for a particular retail outlet(s) for the purchase of fruits and vegetables in urban Ibadan. The objective of our study was to:

1. determine the factors that are responsible for the most preferred retail outlet where customers purchase fruits and vegetables;

2. determine factors influencing the frequency of visits of a customer to a preferred retail outlet.

\section{LITERATURE REVIEW}

\section{Importance of fruits and vegetable}

The importance of fruits and vegetables in daily diet is indispensable as recommended by World Health Organization. Vegetable constitutes the most important and inexpensive component of a balanced diet, which people now realize due to their high nutritive values indispensable for the body adequate functioning (Bvenura \& Sivakumar, 2017). A robust body of evidence supports the recommendations for people to consume a diet rich in fruits and vegetables to reduce their risk of noncommunicable chronic diseases (NCDs), including cardiovascular disease, stroke, and cancer (Raaijmakers et al., 2018; Englund et al., 2020). Recognizing these benefits, governmental agencies and non-government organizations (NGOs) have undertaken a range of farm-to institution initiatives to improve access of institutional clients to fresh produce from small scale fruit and vegetable farmers (Boys et al., 2017). Apart from their economic importance, they are forest and environmentally friendly to fight against drought, use as shade, firewood, food security, agro industry, export, etc. Fruits account for a substantial fraction of world's agricultural output and some of such as apple have acquired extensive cultural and symbolic meanings. Despite its importance the daily consumption of vegetables is insufficient in Nigeria (Olatona et al., 2018). Reliable data on food intake in populations in developing countries (including Nigeria) are scarce and limited, meaning that the mentioned numbers may deviate from actual consumption (Raaijmakers et $\boldsymbol{a l}$., 2018). In the latest national survey $12.4 \%$ of the households reported to consume leafy vegetables, and $16.3 \%$ consumed non-leafy vegetables, at least once or twice per week. In urban areas, $11.1 \%$ of the households indicated to consume at least once or twice a week leafy vegetables and $16.6 \%$ indicated to consume non-leafy vegetables at the same frequency (Maziya-Dixon, 2004).

\section{Fruits and Vegetables Retail Outlets}

Traditional market is a market with little central control or organization, lacks refrigeration, and does not process fresh foods into branded goods for sale (Trappey \& Lai, 1997). According to Pricewaterhouse Coopers (2006) and Pandit et al. (2020) convenience stores are located in major urban centers and along highways to capture those consumers who prefer convenience where they offer a greater variety of products, longer hours of operation and lower prices compared to the traditional grocery stores. Locally grown foods can offer health benefits as well. As produce harvested closer to its peak maturity can offer more health-promoting benefits and as fresh produce can quickly lose its nutrient value after harvest (Bvenura \& Sivakumar, 2017), locally grown produce can be more nutritionally dense. These retail outlets specialise in selling a broad variety and range of fresh fruits and vegetables purchased directly from growers/producers or wholesalers for locally produced ones while they get imported/exotic fruits and vegetables mainly from wholesalers and middlemen (Tedesco et al., 2021). These retailers are largely located in open air markets in dedicated fruits and vegetables section among other stalls, but they are also commonly found in small neighbourhood or street markets, roadside kiosks, cart pushers/street hawkers and in large supermarkets or shopping malls. Nigeria retail food sector consists of supermarkets, convenience stores/small groceries, and traditional, openair markets sharing $1.0 \%, 34 \%$ and $65 \%$ of total retail food sales, respectively Nzeka (2011). Additionally, in spite of 
the urban renewal project of governments and their bias for the promotion of modern retail outlets, traditional open-air retail outlets are still the most frequented outlets in Africa and some other countries in the world. This assertion is corroborated by Meng et al. (2014) in their study in Ghana where open-air markets were found to continue to dominate the food retail system in Ghana, with $70 \%$ of households reporting to patronize them "once a week" or "more than once a week" and that open-air markets are traditional food outlets particularly attractive to large households in Accra. Similar situations also occur outside the African continent as Meng et al. (2014) quoted the research works of Faiguenbaum et al. (2002) where it was stated that, in Chile, the traditional markets still compete strongly in the fruit and vegetable sub-sector, and that the ability of traditional markets to compete is a result of consumer perceptions that traditional markets offer both good prices and freshness (Goldman et al. 2002) and also that in several large Chinese cities, about $49 \%$ of consumers reported buying the bulk of their fresh vegetables from supermarkets (Hu et al. 2004). Gido et al. (2016) revealed in their work that local open air markets and green groceries were the most preferred retail outlets in rural and urban households, respectively in Kenya for African indigenous vegetables (AIV). More so, gender, age and educational level of the key decisionmaker, household size, varietal diversity, vegetable bunch size, market distance and perceptions regarding AIV retail prices significantly influenced the choice for AIV retail outlets (Salanieta et al., 2021).

\section{Marketing fruits and vegetables}

The dramatic increase in consumption of fruit and vegetable products in the world makes it even more relevant to develop effective export marketing strategies aimed at ensuring competitiveness (Ahmadjanovna, 2020). The middlemen and poor supply chain facilities have increased agricultural prices up to $60 \%$ without actually adding any value (Behera $\boldsymbol{e t} \boldsymbol{a l} ., 2015$ ). The internationalization of markets (particularly supply competition) and the increased emphasis on value-added characteristics are two important features that changed the marketing and distribution system in the fruit and vegetable sector (Pandit et al., 2020). Thus, in about two decades, marketing of fruit and vegetables has undergone profound changes, moving from a traditional model based on a large number of operators and on simple transactions (daily, price, class, and volume specifications) between shippers and buyers in wholesale markets. As a result of the current trends, the fruit and vegetable supply chain presents a complex and diversified organizational structure from country to country. This depends on multiple factors: the nature of the produce, the characteristics of production structures, the level of innovation technology and the role of actors along the supply chain. The actors play different roles according to structural and operational features such as the volume of the agricultural production marketed, the fragmentation of farms, and the development of modern distribution and retail systems, which require performing organizational systems, adequate size and logistic platforms (Camanzi et al., 2011).

\section{DATA AND METHODS}

\section{The Study rea}

The study was carried out in Ibadan, Oyo State in the southwest geopolitical zone of Nigeria. Ibadan is the capital of Oyo State, located in the south-eastern part of Oyo State. It has a population of about 4 million (Adelekan, 2016). It is the most urban and metropolitan area in the State with the presence of shopping malls having notable international and local supermarkets, banks, recreation centers, hotels, etc. The city has numerous convenience/neighbourhood stores and a sizeable number of open-air traditional markets where they retail fruits and vegetables. The city also contains a good mixture of both the high, middle, and low-income earners with the location of the supermarkets, convenience stores, and the open-air markets fairly distributed within the city. There are eleven (11) Local Governments Areas in Ibadan consisting of five (5) urban local governments in the city and six (6) in peri-urban.

\section{Sources of Data}

Primary data were used for the study derived from structured questionnaires designed for fruits and vegetable customers within the chosen study areas. Data were obtained on the socio-economic characteristics of the consumers, frequency of purchase (daily, weekly or monthly) and where (open markets, convenience stores, or supermarkets) they purchase fruits and vegetables, amount spent (daily/weekly) on fruits and vegetables, the characteristic features of retail outlets and reasons for customers' decision to visit the retail outlets.

\section{Sampling Procedure}

A multi-stage random sampling technique was used for this study. The first stage was the purposive selection of the five (5) urban LGAs out of the eleven (11) LGAs in Ibadan. The selected LGAs are Ibadan North (Agodi Gate), Ibadan North-East (Iwo road), Ibadan North-West (Onireke/Jericho), Ibadan South-West (Ring road) and Ibadan South-East (Mapo/oje). The second stage involved the randomly sampling of the open-air market (see Table 1) within the selected LGAs The third stage included the selection of individual shoppers at different open-air markets. The selection was done by positioning enumerators at major roads/intersections, retail stores, and markets within the chosen areas where there was significant human traffic; the enumerators randomly selected, approached, and questionnaires were administered to the customers. Informed consent was obtained from respondents before questionnaires were administered to the respondents. A total of 290 responses were eventually retrieved, while 10 questionnaires were returned incomplete. Table 1 showing the distribution of how the sampling technique was undertaken.

\section{Econometric model specification}


The study employed multinomial logistic regression to analyse the influence socioeconomic and demographic factors on the choice of preferred retail outlets and frequency of visit to retail outlets by the consumers.

The Multinomial regression model for categorical dependent variable with $K$ levels in series of $K-1$ equation, one for each independent odds, with each equation consisting of an intercept and B predictors.

Assuming that the last or $K_{t h}$, category of the dependent variable is the proxy or reference category, the equations are expressed in Equation 1 - Equation 5.

$$
\begin{aligned}
& \log O_{1}=\alpha^{1}+\beta_{1} X_{1}+\beta_{2} X_{2}+\cdots+\beta_{b} X_{b} \\
& \log O_{2}=\alpha^{2}+\beta_{1}^{2} X_{1}+\beta_{2}^{2} X_{2}+\cdots+\beta_{b}^{2} X_{b} \\
& \log O_{1}=\alpha^{3}+\beta_{1}^{3} X_{1}+\beta_{2}^{3} X_{2}+\cdots+\beta_{b}^{3} X_{b} \\
& \log O_{k-1}=\alpha^{k-1}+\beta_{1}^{k-1} X_{1}+\beta_{2}^{k-1} X_{2}+\cdots+ \\
& \beta_{b}^{k-1} X_{b} \\
& \operatorname{LogRETAILOUTLETS} \text { OUT }_{k-1}=\alpha^{k-1}+\beta_{1}^{k-1} X_{1}+ \\
& \beta_{2}^{k-1} X_{2}+\ldots+\beta_{b}^{k-1} X_{b}
\end{aligned}
$$

Where:

$\log _{\text {retail outlets }} \log$ of choice of retail outlets/frequency of visit;

$\mathrm{k}-1$ number of equation;

$\mathrm{k}$ representing logits;

$\beta$ coefficient;

$X_{b}$ socioeconomic and demographic characteristics of respondents.
The $X_{S}$ in the equation above are independent variables. As in logistic regression with binary response, parameters are estimated by maximizing the likelihood function for the sample responses on the dependent variable (Chukwuone, 2009).

Thus, Multinomial logit regression analysis was used to examine the determinants of the most preferred retail outlets where customers purchase fruits and vegetables.

Likewise, Multinomial logit regression analysis was also used to determine the factors that influence frequency of visit of a customer to a preferred retail outlet following Bond et al., (2009) (Equation 6).

$$
P_{j}=P\left(Y_{j}=K / X_{j}\right)=\frac{\exp \left(\beta_{o j}+\sum_{k} \beta_{1 k} x j k+\varepsilon_{j}\right)}{\sum_{i=1}^{j} \exp \left(\beta_{o i}+\sum_{k} \beta_{1 k} x i k+\varepsilon_{i}\right)}
$$

Where:

$Y_{i}$ categories of frequency of visit of a customer to a preferred retail outlet: $Y_{0}=$ Daily, $Y_{1}=$ Weekly, $Y_{2}=$ Monthly.

Likewise,

$Y_{i}$ categories of choice of retail outlets for purchase of

\begin{tabular}{|c|c|c|}
\hline \multirow{7}{*}{$\begin{array}{ll}\text { SN } \quad \text { LGAs } \\
1 . \quad \text { Ibadan north }\end{array}$} & Surveyed Locations & Number of Respondents \\
\hline & Bodija market & 10 \\
\hline & Bodija estate & 10 \\
\hline & Ashi road & 10 \\
\hline & Sango & 10 \\
\hline & Agbowo/ui & 10 \\
\hline & Poly road & 10 \\
\hline
\end{tabular}
fruits and vegetable: $Y_{0}=$ Open air market, $Y_{1}=$ Neighbourhood stores, $Y_{2}=$ Supermarket, $Y_{3}=$ Combination of open market, neighbourhood, and supermarket.

Table 2 present the measurement of the explanatory variable.

Table 1: Overview of randomly selected respondents from the surveyed locations

2 Ibadan south east Oje market 20

Oja oba $\quad 10$

Beere $\quad 10$

Bode/molete $\quad 10$

Oke ado $\quad 10$

3 Ibadan north east Iwo road 20

Bashorun 20

Akobo 20

4 Ibadan south west Challenge 15

Ring road/shoprite 15

Oluyole estate $\quad 15$

Felele/pinnacle area 15

5 Ibadan north west Sabo/mokola 15

Dugbe 15

Eleyele $\quad 15$

Jericho/aleshinloye 15

Total 300


Table 2: Explanatory variables used in the study

\begin{tabular}{|c|c|c|c|}
\hline Choice of most preferred retail outlets & $\begin{array}{l}\text { Apriori } \\
\text { expectation }\end{array}$ & $\begin{array}{l}\text { Frequency of visit of a customer to a } \\
\text { preferred retail outlet }\end{array}$ & $\begin{array}{l}\text { Apriori } \\
\text { expectation }\end{array}$ \\
\hline $\begin{array}{l}\mathrm{X}_{1} \text { Affordable price of fruits and } \\
\text { vegetables (Yes }=1,0=\text { otherwise). }\end{array}$ & + & $\begin{array}{l}X_{1} \text { shopping habit of customers } \\
(1=\text { "planned", } 0=\text { ="otherwise") }\end{array}$ & + \\
\hline $\begin{array}{l}X_{2} \text { Proximity/Nearness to the retail outlet } \\
\text { (Yes }=1,0=\text { otherwise). }\end{array}$ & + & $\begin{array}{l}\mathrm{X}_{2} \text { Amount spent on fruits and } \\
\text { vegetables by customers (Naira) }\end{array}$ & + \\
\hline $\begin{array}{l}X_{3} \text { Freshness of the fruits and vegetables } \\
\text { (Yes }=1,0=\text { otherwise). }\end{array}$ & + & $\begin{array}{l}\mathrm{X}_{3} \text { Availability of fruits and vegetables } \\
\text { at the retail outlets (Yes }=1,0=\text { otherwise) }\end{array}$ & + \\
\hline $\begin{array}{l}\mathrm{X}_{4} \text { Hygiene consideration of the retail } \\
\text { outlet (Yes }=1,0=\text { otherwise). }\end{array}$ & $+/-$ & $\begin{array}{l}\mathrm{X}_{4} \text { Customer service offered by the retail } \\
\text { outlets (Yes }=1,0=\text { otherwise) }\end{array}$ & + \\
\hline $\begin{array}{l}\mathrm{X}_{5} \text { Household size of the customers } \\
\text { (number) }\end{array}$ & $+/-$ & $\begin{array}{l}X_{5} \text { Freshness of the fruits and vegetables } \\
\text { (Yes }=1,0=\text { otherwise) }\end{array}$ & + \\
\hline $\mathrm{X}_{6}$ Age of customers (years) & $+/-$ & $\begin{array}{l}\mathrm{X}_{6} \text { Storage facility by the customers } \\
\text { (Yes }=1,0=\text { otherwise) }\end{array}$ & + \\
\hline $\mathrm{X}_{7}$ Formal education of customers (years) & $+/-$ & $\begin{array}{l}\mathrm{X}_{7} \text { Household size of the customer } \\
\text { (number) }\end{array}$ & $+/-$ \\
\hline $\begin{array}{l}\mathrm{X}_{8} \text { Occupation of customers }(1=\text { "public } \\
\text { salaried", } 0=\text { "otherwise") }\end{array}$ & $+/-$ & $\begin{array}{l}\mathrm{X}_{8} \text { Competitive pricing of fruits and } \\
\text { vegetables at the outlet (Yes=1, } 0= \\
\text { otherwise) }\end{array}$ & $+/-$ \\
\hline $\begin{array}{l}\mathrm{X}_{9} \text { Total household income of the } \\
\text { customers (Naira) }\end{array}$ & + & $\begin{array}{l}\mathrm{X}_{9} \text { Occupation of customers (1="public } \\
\text { salaried", } 0=\text { "otherwise") }\end{array}$ & $+/-$ \\
\hline
\end{tabular}

\section{RESULTS AND DISCUSSION}

Frequency distribution of consumers' purchases of fruit and vegetable (Table 3) shows that $27.59 \%$ of the respondents purchase fruits and vegetables on a weekly basis, while $18.97 \%$ purchase fruits and vegetables on daily basis. Regarding frequency of purchase, about $52.76 \%$ of respondents purchase fruits and vegetables on both daily, weekly and monthly basis.

Table 3: Frequency Distribution of Purchase by Consumers

\begin{tabular}{lcc}
\hline Frequency of Purchase & Frequency & Percentage \\
\hline Daily & 55 & 18.97 \\
Weekly & 80 & 27.59 \\
Monthly & 2 & 0.69 \\
Combination of Daily, Weekly & 153 & 52.76 \\
and Monthly & & \\
Total & 290 & 100.00 \\
\hline
\end{tabular}

Source: Field Survey 2017

\section{Retail Outlet for the Purchase of Fruits and Vegetables by} Customers

The results of the most preferred retail outlet for the purchase of fruits and vegetables by consumers is presented in Table 4 . The findings from the study shows that customers who purchased fruits and vegetables from different retail outlets. Regarding open market retail, about $33.10 \%$ of consumers buy their fruits and vegetables from open air market. Likewise, about $15.17 \%$ engage supermarket, while neighbourhood stores only have the lowest patronage with $5.52 \%$. The majority $(46.21 \%$.) of the consumers patronize more than one retail outlets. The percentage of respondents who engage open market retail outlet only for the purchase of fruits and vegetables is a confirmation of the widely documented fact that the traditional retail channel still the most and commonly accessible food outlet by households in developing countries, Nigeria inclusive. This finding agree with the findings of Chamhuri \& Batt (2013), Gido et al., (2016), Meng et al., (2014) Mącik et al., (2013) that open market is commonly used by households.

\section{Determinants of the Most Preferred Retail Outlets for the Purchase Fruits and Vegetables by Customers}

Table 5 shows a multinomial logit regression result on the determinants of the most preferred retail outlet for the purchase of fruits and vegetables in urban Ibadan. The Chi-Square statistics is significant (at $1 \%$ probability level) which shows the goodness of fit of the model. The three categories of the dependent variables used here are Open-markets, Neighbourhood/Convenience Stores, and Supermarkets. The base category adopted is the combination of these three categories.

Firstly, household size is positively and statistically significant (at $10 \%$ probability level) for selecting an open market retail channel for the purchase of fruits. This implies that a unit increase in a household size will increase the probability of a household's purchase in the open market by $4.3 \%$ relative to more than one retail outlet. In other words, the larger the household size, the more likely it is that the household will purchase fruits and vegetables from an open market compare to a combination of the three retail outlets. This may be due to the fact that fruits and vegetables in open markets are perceived to be cheap which makes the channel more desirable for families with large family sizes as it affords them the opportunity to purchase a large number of fruits and vegetables at a cheaper price. According to Meng et al. (2014), larger households shop for foods in open-air markets more frequently. This also confirm the findings of Adams et al., (2020) that household size is important factor that influence the choice of retail outlets. Likewise, proximity is positively and statistically significant (at $10 \%$ probability level) in determining respondents' choice of open market as a retail outlet they engage with. This means that close distance to an open market retail channel is to a respondent increases the probability of purchasing from there by $30 \%$. Panda (2013) opined that the major benefits of the traditional markets (open markets) over the modern markets are related to the convenience of location, customized services, and ease of 
goods return or exchange policy. Product freshness was however found to be negatively and statistically significant (5\% probability level) in determining the household choice of open market as a retail outlet for the purchase of fruits and vegetables. Respondents show that they have a $30 \%$ less probability of purchasing fruits and vegetables in the open market when freshness is under consideration. This implies that respondents would prefer the choice of the three retail outlets when considering freshness as a factor for determining the purchase of fruits and vegetables. This may be due to the perception among respondents whose majority are highly educated $(57.93 \%)$ that open market retail outlets are unsuitable for purchasing fruits and vegetables because of the unhygienic nature of the open-market environment which impacts the product quality. Meng $\boldsymbol{e t}$ al. (2014) found that college-educated households have a lower probability of shopping for food in open-air markets, because an open-air market may not meet their high expectations for food quality.

Secondly, regarding engaging neighbourhood stores, sex and number of persons working in a household are statistically significant. The sex of respondents is found to be positively and statistically significant (10\% probability level). This implies that being a male customer increases the probability of purchasing from neighbourhood stores by $5 \%$, it indicates that male respondents would rather prefer to visit neighbourhood convenience stores as compared to the combination of the three retail outlets. According to Panda (2013), Kiranas (a type of neighbourhood/convenience store in India) are perceived to be better than the organized retailers in terms of extending credit and phone order services and this is possible due to the familiarity of the customers with the local shop owners and goodwill. The product quality is perceived to be better at neighbourhood outlets especially for food and grocery items because of the choice of freshness in the case of food products in India. Likewise, the number of people working in a household is positively and statistically significant (5\% probability level). This depicts that an additional working adult in a household increases the probability of purchasing fruits and vegetables in a neighbourhood store by $5 \%$, this implies that the higher the number of persons working in a household, the higher the likelihood they will purchase their fruits and vegetables from neighbourhood/convenience store as against the combination of the three retail outlets. As Meng et al., (2014) confirmed that income significantly influences where consumers shop, it is expected that the more money available for the purchase of food in a household, the higher the level of convenience that will be sought by the household as the total household income would have increased. Likewise, Iton (2017) predicts income as important element in the choice of retail outlet. As the number of persons working in a household increases, there will be less time dedicated for long hour shopping and thus will prefer to purchase within the neighbourhood due to closeness and convenience as PriceWaterhouseCoopers (2006) found that convenience stores are located in major urban centers and along highways to capture those consumers who prefer convenience where they offer a greater variety of products, longer hours of operation and lower prices compared to the traditional grocery stores. This also support the finding of Tanwar (2015).
Thirdly, regarding supermarket as retail outlet choice, the number of persons working in a household, total household income, affordability, and public salaried are statistically significant. Total household income is positively and statistically significant $(5 \%$ probability level) for the choice of the supermarket as a retail outlet for fruits and vegetable purchase. This result is consistent with the findings of Meng et al. (2014) that posits income has a significant positive influence on food shopping frequency in supermarkets. However, the marginal effect of the total household income as a result of the total number of working persons in the household was found to be negligible. This also confirms the result from Meng et al. (2014) who posited that although income is an essential factor for buying food in a supermarket, the magnitude of its effect is still quite small. The negligible marginal effect of total household income notwithstanding, the wide diversity of products including both food and non-food items makes a supermarket the most convenient one-stop store for large households especially those consisting of two or three generations (Meng et al., 2014). The result also shows that public salaried (work type) is positively and statistically significant $(10 \%$ probability level $)$ in determining the household choice of Supermarket as a retail outlet for fruits and vegetable purchase. It is, however, instructive to note from the result that the salary earned by public servants have a very negligible effect on the probability of public salaried respondents purchasing fruits and vegetables from supermarket retail outlet. This negligible purchasing probability by public salaried respondents may be attributable to the epileptic and inconsistent monthly salary payment of these workers as the government is owing to a backlog of unpaid salaries.

The result from this study is similar to the report by Ohen $\boldsymbol{e t}$ al., (2014) where the result from their ordered probit regression indicated that the frequency of monthly purchase of fruits and vegetables among civil servants in Essien Udim LGA, Akwa Ibom State, Nigeria was significantly determined by the monthly income of the workers while other variables such as age, sex, marital status, and educational level had no significant effect on the frequency of monthly purchase. Additionally, affordability was found to be positively and statistically significant (1\% probability level) for the purchase of fruits and vegetables at the supermarket retail outlet as compared against the combination of the three retail outlets. Affordability as a factor however has a very low or nearly negligible probability of $0.002 \%$ to be an important factor to entice a customer to purchase from a supermarket. Supermarket purchase is seen among the customers as a status symbol often frequented by the high and middle-income households who can afford the non-negotiable shelf prices of the various products in the outlet. To these high and middle-income earners, supermarket prices are not enough hindrance to purchasing from there as Chaiyasoonthorn \& Suksa-ngiam (2011) found that factors correlated with the purchase of goods and services from modern retail stores (supermarket inclusive) were a distance from home, distance from the workplace, purchase intention, customer satisfaction, perceived service quality, personal income, and household income.

Table 4: Distribution by the Most Preferred Retail Outlet for the Purchase of Fruits and Vegetables by Consumers

\begin{tabular}{lll}
\hline Retail outlet & Frequency & Percentage \\
\hline Open market & 96 & 33.10 \\
Neighbourhood/Convenience Stores & 16 & 5.52 \\
Super market & 44 & 15.17 \\
Combination Open market, & 134 & 46.21 \\
Neighbourhood Stores and Supermarkets & & \\
Total & 290 & 100 \\
\hline
\end{tabular}


Source: Field Survey 2017

Table 5: Determinants of the Most Preferred Retail Outlets for the Purchase of Fruits and Vegetables by Customers

\begin{tabular}{|c|c|c|c|c|c|}
\hline Where purchases made & Coef. & Std. Err. & dydx & $\mathrm{Z}$ & $\mathrm{P}>\mathrm{Z}$ \\
\hline \multicolumn{6}{|l|}{ Open market } \\
\hline Sex & 0.014 & .305 & -.016 & 0.05 & 0.962 \\
\hline Years of Education & -0.053 & .039 & -.012 & -1.36 & 0.174 \\
\hline Household size & 0.174 & .101 & .042 & 1.72 & $0.086^{*}$ \\
\hline Number of persons working & -0.228 & .250 & -.072 & -0.91 & 0.362 \\
\hline Public salaried & -0.186 & .382 & -.031 & -0.49 & 0.626 \\
\hline Proximity & 1.273 & .743 & .295 & 1.71 & $0.087 *$ \\
\hline Affordability & 0.439 & .570 & -.096 & -0.77 & 0.441 \\
\hline Hygiene & 0.217 & .339 & .045 & 0.64 & 0.521 \\
\hline Freshness & -1.379 & .692 & -.300 & -1.99 & $0.046 * *$ \\
\hline $\begin{array}{l}\text { Total amount fruits and } \\
\text { vegetable }\end{array}$ & 8.080 & .000 & 6.910 & 0.23 & 0.821 \\
\hline Total household income & -1.820 & 1.760 & -3.750 & -1.04 & 0.300 \\
\hline cons & 0.603 & 1.159 & & 0.52 & 0.602 \\
\hline \multicolumn{6}{|l|}{ Neighborhood Stores } \\
\hline Sex & 1.022 & .598 & .049 & 1.71 & $0.088 *$ \\
\hline Years of Education & 0.0186 & .086 & .001 & 0.21 & 0.831 \\
\hline Household size & -0.091 & .202 & -.007 & -0.45 & 0.651 \\
\hline Number of persons working & 1.004 & .419 & .053 & 2.39 & $0.017 * *$ \\
\hline Public salaried & -.628 & .843 & -.027 & -0.75 & 0.456 \\
\hline Proximity & 0.178 & 1.205 & -.015 & 0.15 & 0.883 \\
\hline Affordability & -0.325 & 1.094 & -.007 & -0.30 & 0.766 \\
\hline Hygiene & 0.265 & .695 & .008 & 0.38 & 0.703 \\
\hline Freshness & -1.186 & 1.304 & -.031 & -0.91 & 0.363 \\
\hline $\begin{array}{l}\text { Total amount of fruits and } \\
\text { vegetable }\end{array}$ & 0.000 & .000 & 2.880 & 1.28 & 0.202 \\
\hline Total household income & -2.680 & 3.780 & -0.960 & -0.71 & 0.478 \\
\hline cons & -3.285 & 2.206 & & -1.49 & 0.137 \\
\hline \multicolumn{6}{|l|}{ Supermarket } \\
\hline Sex & 0.149 & .904 & 0.005 & 0.17 & 0.868 \\
\hline Years of Education & -0.166 & .126 & -0.801 & -1.31 & 0.191 \\
\hline Household size & -0.137 & .263 & -0.108 & -0.52 & 0.602 \\
\hline Number of persons working & 1.171 & .530 & 0.657 & 2.21 & $0.027 * *$ \\
\hline Public salaried & 1.511 & .849 & 0.880 & 1.78 & $0.075^{*}$ \\
\hline Proximity & -0.860 & .904 & -0.735 & -0.95 & 0.341 \\
\hline Affordability & -5.483 & 1.070 & -.000 & -5.12 & $0.000 * * *$ \\
\hline Hygiene & 26.48078 & 1251.725 & .0001439 & 0.02 & 0.983 \\
\hline Freshness & 18.40245 & 3009.234 & .0001035 & 0.01 & 0.995 \\
\hline $\begin{array}{l}\text { Total amount fruits and } \\
\text { vegetable }\end{array}$ & 0.0000439 & .0000709 & $2.06 \mathrm{e}-10$ & 0.62 & 0.535 \\
\hline Total household income & $9.24 \mathrm{e}-06$ & $4.22 \mathrm{e}-06$ & $5.49 \mathrm{e}-11$ & 2.19 & $0.029 * *$ \\
\hline cons & -43.11971 & 3259.17 & & -0.01 & 0.989 \\
\hline
\end{tabular}

Combination of more than (base outcome)

one outlet

Number of observations $=290$ LR chi2 $(33)=218.66 \quad$ Prob $>$ chi2 $=0.0000$ Log likelihood $=-229.58097$

Pseudo $\mathrm{R} 2=0.3226, *, * *, * * *$, indicates $0.1,0.05,0.01$ probability level respectively.

Source: Field Survey 2017

Drawing from this conclusion, it is, therefore, safe to say that affordability is given whenever a resident decided to purchase fruits and vegetables at the supermarket retail outlet as Meng $\boldsymbol{e t}$ al. (2014) puts it that high-income and well-educated households, who buy regularly in supermarkets, are more likely to consume healthy food items including imported vegetables and fruits, as well as new highly nutritious food products because a typical supermarket has a wide selection of food products, and offerings that may include but are not limited to out-of-season vegetables and fruits or international products with high nutritional density.
Factors Influencing Frequency of Visit of a Consumer to the Preferred Retail Outlet

Table 6 shows a multinomial logit regression result on the factors influencing the frequency of visits of a consumer to a preferred retail outlet for the purchase of fruits and vegetables in urban Ibadan. The Chi-Square statistics are significant at a $1 \%$ probability level which shows the goodness of fit of the model. The three categories of the dependent variables examined in this study are: daily, weekly, and a combination of both daily and weekly purchases. The monthly purchase frequency wasn't 
considered because the observations were insignificant, thus negligible.

Firstly, the variables that are statistically significant under the daily frequency of purchase are the total amount spent on fruits and vegetables, shopping habits, and customer service. The total amount allocated to the purchase of fruits and vegetables was found to be negatively and statistically significant $(10 \%$ probability level) in determining the consumer daily purchase of fruits and vegetables. It can be inferred that because of the price of fruits and vegetables, respondents are less likely to be willing to do daily purchase rather they will want more of the combination of the purchasing frequencies. This might be true of households with large sizes who may want to take advantage of weekly bulk. The result also indicated that shopping habit was found to be negatively and statistically significant $(10 \%$ probability level $)$ in determining if a consumer will daily purchase fruits and vegetable. Consumers have a $15 \%$ less probability of daily shopping for fruits and vegetables. Customer service is positively and statistically significant $(5 \%$ probability level) in determining if consumers will daily purchase fruits and vegetables as against the combination of both. Excellent customer service makes customer feels wanted and that the retailer cares about developing a long-term relationship that means more than just making a one-off sale. The result means that the better services a customer gets from the retailer of fruits and vegetables the higher the likelihood that such customer will daily purchase fruits and vegetables from such outlet. Consumers desire not just satisfaction of a product bought but also the satisfaction of service rendered and thus will frequently visit retail outlets where both are adequately available and given. This agrees with the findings of Macik et al. (2013) that consumers have different preferences for the choice of their retail food outlets. Good customer service also inspires loyalty among customers which leads to a good reputation for the retail outlet and eventually long-term business growth. This is a win-win situation for both customers and retailers.

Secondly, regarding the weekly frequency of purchase fruits and vegetables, the significant factors include the sex of the customer, household size, total household income, and shopping habits of the customers. The sex of customers was found to be positively and statistically significant $(5 \%$ probability level) in determining if a customer will purchase fruits and vegetables weekly. The result indicated that male customers have a $12 \%$ probability of weekly fruits and vegetable purchases as against the combination of the three purchase frequencies. This is similar to the findings of Ogundari \&Arifalo (2013) and Yen et al., (2011).

Table 6: Factors Influencing Frequency of Visit of a Customer to a Preferred Retail Outlet

\begin{tabular}{|c|c|c|c|c|c|}
\hline $\begin{array}{l}\text { Frequency of Purchase of Fruits and } \\
\text { Vegetables }\end{array}$ & Coef. & Std. Err. & $\mathrm{dy} / \mathrm{dx}$ & $\mathrm{Z}$ & $\mathrm{P}>\mathrm{Z}$ \\
\hline \multicolumn{6}{|l|}{ Daily Purchase } \\
\hline Age of customer & -.012 & .016 & -.001 & -0.74 & 0.458 \\
\hline Sex of customer & .0187 & .390 & -.021 & 0.05 & 0.962 \\
\hline Years of formal education & .042 & .052 & .003 & 0.81 & 0.419 \\
\hline Household size & .033 & .117 & -.002 & 0.28 & 0.778 \\
\hline Total amount spent on fruits and vegetable & -.000 & .000 & -.000 & -1.78 & $0.075^{*}$ \\
\hline Total household income(Primary) & 0.271 & 0.178 & 0.473 & 1.52 & 0.128 \\
\hline Public salaried & -.147 & .436 & -.036 & -0.34 & 0.736 \\
\hline Storage facility & -.013 & .380 & .002 & -0.03 & 0.973 \\
\hline Shopping habit & -.929 & .475 & -.153 & -1.96 & $0.051 *$ \\
\hline Customer service & .756 & .385 & .082 & 1.96 & $0.050 * *$ \\
\hline Availability of fruit and vegetable & .876 & .524 & .114 & 1.67 & 0.095 \\
\hline cons & -0.207 & 1.118 & & -1.86 & 0.063 \\
\hline \multicolumn{6}{|l|}{ Weekly Purchase } \\
\hline Age & .011 & .016 & .002 & 0.69 & 0.488 \\
\hline Sex & .655 & .322 & .124 & 2.03 & $0.042 * *$ \\
\hline Years of Education & .036 & .045 & .005 & 0.80 & 0.422 \\
\hline Household size & .169 & .102 & .031 & 1.66 & $0.097 *$ \\
\hline Total Amount spent on fruit and vegetable & .000 & .000 & 0.000 & 0.96 & 0.338 \\
\hline Total household income(Primary) & -0.385 & 0.002 & -0.000 & -1.93 & $0.054 *$ \\
\hline Public salaried & .494 & .385 & .099 & 1.28 & 0.200 \\
\hline Storage facility & -.107 & .352 & -.019 & -0.30 & 0.761 \\
\hline Shopping habit & 1.089 & .326 & .241 & 3.33 & $0.001 * *$ \\
\hline Customer service & .272 & .365 & .024 & 0.75 & 0.456 \\
\hline Availability of fruits and vegetables & -.183 & .381 & -.067 & -0.48 & 0.629 \\
\hline cons & -2.847 & .919 & & -3.10 & $0.002 * *$ \\
\hline Combination of Daily, Weekly and both & (base & & & & \\
\hline Daily and Weekly & outcome) & & & & \\
\hline
\end{tabular}

Notes: Number of observations = 288; LR chi2(22) = 77.89; Prob > chi2 = 0.0000; Pseudo R2 = 0.1341; Log likelihood = -251.36598. $*$, **, ***, indicates $0.1,0.05,0.01$ probability level respectively.

Source: Field Survey 2017 
According to Ogundari \& Arifalo (2013), the probability of consumption and the demand for vegetables decrease significantly with household size, educational level of the head, and among households headed male. In the same vein, Yen et al., (2011) stated that the effects of gender as a determinant of fruits and vegetable consumption suggests that men consume fewer fruits while the effects on vegetables are insignificant. Likewise, household size is positively and statistically significant ( $10 \%$ probability level) in determining if a customer will purchase fruits and vegetables weekly. The probability of a household purchasing fruits and vegetables weekly rather than daily or monthly is $3 \%$ showing therefore that the larger the family size, the more likely the household will prefer weekly purchases as against the combination of the three frequencies. In contrast to this finding, however, the result from the work of Meng et al. (2014) states that one additional adult to a household increases the probability of buying food in supermarkets "more than once a week" by $4.8 \%$. Total household income is negatively and statistically significant $(10 \%$ probability level) in determining if a customer will purchase fruits and vegetables weekly. This means it is less likely higher total household income will make consumers purchase fruits and vegetables weekly. This finding is against the apriori expectation from this study because of the high level of formal education and the health benefit awareness level of the customers but it is a confirmation of the result of Ogundari \& Arifalo (2013) that the demand for fruit responds slowly to rise in income among low-income households in Nigeria._shopping habit is positively and statistically significant (1\% probability level) for weekly purchase of fruits and vegetables as earlier discussed. The respondents' shopping habits have a $2 \%$ probability of influencing the weekly purchase of fruits and vegetables as against the combination of the three frequencies. Customers believe that adhering to a weekly frequency of shopping will encourage them to practice planned shopping by drawing up a list of needed home essentials rather than unplanned or impulse shopping. Planned shopping affords customers to save money while impulse shopping makes them spend more than expected.

\section{CONCLUSION AND POLICY RECOMMENDATION}

Most households in urban Ibadan purchased their fruits and vegetables more on a weekly than on daily basis. Education and awareness of nutritional benefits had a positive effect on the daily and weekly consumption patterns of fruits and vegetables. Despite the increasing development and recorded growth of modern retail stores within urban Ibadan, the traditional open market retail channel still commands the highest percentage patronage among urban households for the purchase of fruits and vegetables; followed by supermarkets and neighbourhood/convenience stores. The freshness and quality of fruits and vegetables and customer convenience are the two most important determinants of customers' choice of different retail outlets as against competitive and affordable prices.
As a result of the findings from this study, it is recommended that:

i. Urban renewal activities should not be an avenue to dislodge or demolish traditional open market outlets, rather, the priority for these existing open-market retail outlets should be to restructure/reorganize them into making the market environment more friendly, convenient, accessible, and hygienic for both the retailers and customers. The restructuring can be in form of efficient waste management (timely evacuation), maintenance of market roads (free flow of human and vehicular traffic), thorough drainages (free flow of waste water and floods), construction of adequate car parks (reduce market roads congestion and eliminates customers' fears of their cars being towed while parked in an unauthorized area), provision of functional public toilets (promote hygiene and prevent communicable diseases), water supply (for drinking and daily essentials) and assurance of security of lives and properties of customers, consumers, and shoppers.

ii. Fruits and vegetables producers and retailers should be quality conscious during the processes of production and handling of fruits and vegetables to preserve the freshness of the products. The preservation of the products' freshness will encourage customers and consumers to frequently visit their preferred outlets for fruits and vegetable purchases thereby enhancing the livelihood of the customers and improving the sales revenue and profitability of the retailers and producers.

iii. Retail outlet owners should strive to create a conducive and friendly atmosphere with their customers to engender an enduring customer service experience to encourage customers' repeat purchases.

\section{Acknowledgement}

We appreciate the efforts of students of the Department of Agricultural Economics, University of Ibadan, Nigeria, who help in data collection and also the staff for criticizing the paper for us to achieve the complete version.

\section{REFERENCES}

ADAMS, F., WONGNAA, C. A., \& COLEMAN, E. (2021). Profitability and choice of marketing outlets: evidence from Ghana's tomato production. Journal of Agribusiness in Developing and Emerging Economies, 11(3). 296-312, https://doi.org/10.1108/JADEE-062019-0090

ADELEKAN, I. O. (2016). Urban African risk knowledge, Ibadan City Diagnostic Report, Working paper 4.

AHMADJANOVNA, M. T. (2020). Methodology Forming the International Marketing Strategy of Fruit and Vegetable Products. International Journal of Psychosocial Rehabilitation, 24(5), https://doi.org/10.37200/I JPR/V24I5/PR2020208

BEHERA, B.S., PANDA, B., BEHERA, R. A, NAYAK, N., BEHERA, A. C., \& JENA, S. (2015). Information communication technology promoting retail 
marketing. In Agriculture Sector in India as a Study, Procedia Computer Science, 48, $652-659$.

BOND, J. K., THILMANY, D., \& BOND, C. (2009). What Influences Consumer Choice of Fresh Produce Purchase Location? Journal of Agricultural and Applied Economics, 41(1), 61-74. https://doi.org/10.1017/S1074070800002558

BOYS, K. A, \& FRASER, A. M. (2018). Linking small fruit and vegetable farmers and institutional foodservice operations: marketing challenges and considerations. Renewable Agriculture and Food Systems, $1-13$, https://doi.org/10.1017/S1742170518000030

CALLISTUS BVENURA, C., \& SIVAKUMAR, D. (2017). The role of wild fruits and vegetables in delivering a balanced and healthy diet. Food Research International, 99, 15-30, http://dx.doi.org/10.1016/j.foodres.2017.06.046

CAMANZI, L., MALORGIO, G., \& AZCÁRATE, T. G. (2011). The role of producer organizations in supply concentration and marketing: a comparison between European countries in the fruit and vegetable sector. Journal of Food Products Marketing, 17(2-3), 327354, https://doi.org/10.1080/10454446.2011.548706

CHAIYASOONTHORN, W., \& SUKSA-NGIAM, W. (2011). Factors affecting customers using modern retail stores in Bangkok. International Conference on Business and Economics Research, 16, 108-112.

CHAMHURI, N., \& BATT, P. J. (2013). Exploring the factors influencing consumers' choice of retail store when purchasing fresh meat in Malaysia. International Food and Agribusiness Management Association, $16(3)$, 99-122. http://hdl.handle.net/20.500.11937/46147

CHUKWUONE, N. A. (2009). Socioeconomic determinants of cultivation of non-wood forest products in southern Nigeria, Biodiversity and Conservation, 18(2), https://doi.org/10.1007/s10531-008-9489-y

ENGLUND, T. R., ZHOU, M., DUFFEY, K. J., \& KRAAK, V. I. (2020). A qualitative study to understand stakeholders' views about the fruits \& veggies (fnv) social marketing campaign to promote fruit and vegetable consumption in the United States. Journal of the Academy of Nutrition and Dietetics, $120(12)$,

1986-1997. https://doi.org/10.1016/j.jand.2020.04.023

GIDO, E. O., AYUYA, O. I., OWUOR, G., \& BOKELMANN, W. (2016). Consumer's choice of retail outlets for African indigenous vegetables: Empirical evidence among rural and urban households in Kenya. Cogent Food \& Agriculture, 2(1). https://doi.org/10.1080/23311932.2016.1248523

HAWEA, S. M. C, SINGH, P., \& WHITING, S. J. (2021). Cultural determinants of fruits and vegetable consumption in indigenous (iTaukei) Fijian children: a qualitative study of caregivers, Asia Pacific Journal of Public Health, $1(6)$ https://doi.org/10.1177/10105395211038458

ITON, A. C. W. (2017). Do demographics predict shoppers' choice of retail outlet for roots and tubers in Trinidad and Tobago? Journal of Agribusiness in
Developing and Emerging Economies, 7(3), 231-241, https://doi.org/10.1108/JADEE-05-2016-0035

KAPOOR, S., \& KUMAR, N. (2015). Fruit and vegetable consumers' behavior: implications for organized retailers in emerging markets. Journal of International Food \& Agribusiness Marketing, 27(3), 203-227, https://doi.org/10.1080/08974438.2014.940118

MĄCIK, R., MĄCIK, D. \& NALEWAJEK M. (2013). Consumer Preferences for retail format choice: case of Polish consumers. Proceedings of the Management, Knowledge and Learning International Conference. 19-21 $1^{\text {st }}$ June 2013. V. Dermol, N. T. Širca, and G. Đaković. Croatia. 935-943.

MAZIYA-DIXON, B. (2004). Nigeria food consumption and nutrition survey 2001-2003: summary; International Institute of Tropical Agriculture: Ibadan, Nigeria.

MENG, T., FLORKOWSKI, J. W., SARPONG, D. B, CHINNAN, M. S. \& RESURRECCION, A. V. A. (2014). Consumer's food shopping choice in Ghana: supermarket or traditional outlets? International Food and Agribusiness Management Review. 17(A). 107129. DOI: $10.22004 / \mathrm{ag}$.econ. 164600

NZEKA, U. M. (2011). Steady Growth of Nigeria's Retail Food Sector. Global Agricultural Information. 21. 1725.

file://wurnet.nl/Homes/adeos001/My\%20Documents/ Retail_Foods_Lagos_Nigeria 12-20-2011.pdf

OGUNDARI, K., \& ARIFALO, S. F. (2013). Determinants of household demand for fresh fruit and vegetable in nigeria: a double hurdle approach. Quarterly Journal of International Agriculture. 52(3), 199-216. DOI: $10.22004 /$ ag.econ.173646

OHEN, S. B., UMEZE, G. E., \& INYANG, E. O. (2014). Consumer purchasing behaviour for fruits and vegetables among civil servants in Essien Udim local government area, Akwa Ibom State, Nigeria. Food Science and Quality Management. 23,55-64.

OLATONA, F., SOSANYA, A., SHOLEYE, O., OBRUTU, O., \& NNOAHAM, K. (2018). Knowledge of fruits and vegetables, consumption pattern and associated factors among adults in Lagos State, Nigeria. Research Journal of Health Sciences, 6, 5062.

PANDA, A. (2013). Customer patronage towards food and grocery retail: a case study. Global Journal of Management and Business Studies. 3(9): 955-960. http://www.ripublication.com/gjmbs.htm

PANDIT, S. S, KUWORNU, J. K. M, DATTA, A, YASEEN, M \& ANAL, A. K. (2020). Analysis of marketing information sources among smallholder vegetable farmers. International Journal of Vegetable Science, 26(1), 96-105, https://doi.org/10.1080/19315260.2019.1609148

PANDIT, S. S., KUWORNU, J. K. M., DATTA, A., YASEEN, M., \& ANAL, A. K. (2020) Analysis of marketing information sources among smallholder vegetable farmers. International Journal of Vegetable Science, 26(1), 96-105, https://doi.org/10.1080/19315260.2019.1609148

PRICEWATERHOUSECOOPERS, (2007). Retailing 2015: New Frontiers. Available: 
https://www.pwc.com/cl/es/publicaciones/assets/retail ing2015.pdf

RAAIJMAKERS, I., SNOEK, H., MAZIYA-DIXON, B., \& ACHTERBOSCH, T. (2018). Drivers of vegetable consumption in urban Nigeria: food choice motives, knowledge, and self-efficacy, Sustainability, 10(4771), 1-14, https://doi.org/10.3390/su10124771

TANWAR, S. (2015). Customer perception on retail service quality: the case of food and grocery retailing. FIIB Business Review, 4(3), 46-55. https://doi.org/10.1177/2455265820150309

TEDESCO, D. E. A., SCARIONI, S., TAVA, A., PANSERI, S., \& ZUORRO, A. (2021). Fruit and vegetable wholesale marketwaste: safety and nutritional characterisation for their potential re-use in livestock nutrition. Sustainability, 13, 9478. https://doi.org/10.3390/su13169478

WHO (2003). WHO fruit and vegetable promotion initiative. Report of the meeting, Geneva, 25-27 August 2003. Publication No. WHO/NMH/NPH/NNP/0308.

YEN, S. T., TAN, A. K. G., \& NAYGA JR, R. M. (2011). Determinants of Fruit and Vegetable Consumption in Malaysia: An Ordinal System Approach. The Australian Journal of Agricultural and Resource Economics. 55, 239-256. https://doi.org/10.1111/j.1467-8489.2011.00536.x 